(c) American Dairy Science Association, 2006.

\title{
Major Advances in Teaching Dairy Production
}

\author{
R. S. Kensinger and L. D. Muller \\ Department of Dairy and Animal Science, The Pennsylvania State University, University Park 16802
}

\begin{abstract}
A survey of 38 universities that grant 4-yr degrees as well as 12 institutions that grant technical degrees of $2 \mathrm{yr}$ or less revealed that degree programs in dairy production remain popular, but have changed significantly over the last $25 \mathrm{yr}$. Enrollment in dairy production programs remains strong (1,189 and 417 students in baccalaureate and nonbaccalaureate degrees, respectively) even though this is viewed as a traditional industry. There are significant differences in size of programs across the United States, and some are struggling to maintain both the visibility and faculty numbers to keep pace with the industry. The percentage of students enrolled in 4-yr programs who are female has increased to the majority. More students hail from a nondairy farm background in our university programs today than in 1994. Computer and information technology has become a mainstream part of our educational programs. A high percentage of undergraduate students elect to engage in an internship or work experience, and there is a high correlation between internship and career paths selected by our students. The dairy industry initiated and financially supports the North American Intercollegiate Dairy Challenge; an educational activity among university teams to foster skills in analyzing a dairy farm business. This collaboration between universities and private industry is strong evidence that our undergraduate programs are relevant to the dairy industry. Extracurricular activities like dairy science clubs also remain popular, and are perceived by faculty members to be an important part of our educational experience. An analysis of nonbaccalaureate degree programs was not reported previously, but was a part of the present survey. In the nonbaccalaureate institutions that responded to the survey, there were $417 \mathrm{stu}-$ dents enrolled in 12 dairy programs across the United States in 2004. This student population in nonbaccalaureate programs has a higher percentage of female enrollment than in 1994, but enrollment is still predominantly male. Computer and information technologies
\end{abstract}

Received June 23, 2005.

Accepted June 30, 2005.

Corresponding author: rsk7@psu.edu or lmuller@psu.edu are an important part of their curricula and a very high percentage of these students remain in production agriculture upon graduation. Many of the challenges in undergraduate education described previously continue to be challenges in 2005 . However, there are many reasons for optimism; as the number of students electing enrollment in dairy production remains strong, there is great interest in keeping the curricula relevant and interaction with and support by the dairy industry continues to be significant.

Key words: dairy production, education, students, enrollment

\section{INTRODUCTION}

The authors have the privilege of providing an update on the important trends in undergraduate teaching programs in dairy science and production since the 75th anniversary issue was published in 1981. Thus, the current review will describe the progress in the state of dairy production education since it was summarized by Etgen and Foreman (1981) in the 75th anniversary issue. Among the notable trends in dairy science education reviewed by Etgen and Foreman for the 25-yr period from 1955 to 1980 were: 1) an increased number of female students; 2 ) a decrease in the number of students from dairy farms; 3) an increase in the number of animal science departments that cover multiple animal species, 4) the loss (to food science departments) of dairy manufacturing; 5) a trend for faculty with more education; 6) an increase in technology and computer use in courses; 7) a small decline in the number of dairy science clubs; and 8) an increased number of graduates who enter veterinary and graduate school. Many of these changes have continued in the subsequent $25 \mathrm{yr}$. We elected to build upon the work of Etgen and Foreman by collecting data from dairy and animal science programs that grant 4-yr degrees, as well as programs that offer 1- or 2-yr degrees in dairy production. Survey data were returned from 38 institutions granting 4-yr degrees and from 12 institutions that grant technical degrees in dairy production. The survey instrument was sent to 60 institutions that grant 4-yr degrees, and to 24 institutions that grant technical degrees.

Important changes have occurred in the dairy industry during the last $25 \mathrm{yr}$, and likely impact dairy science 
Table 1. A profile of the dairy industry for benchmark years

\begin{tabular}{lccc}
\hline Measure & 1981 & 1994 & 2004 \\
\hline Dairy cows, ${ }^{1}$ (millions) & 10.9 & 9.5 & 9.0 \\
Dairy farms, ${ }^{1}$ (no.) & 320,160 & 148,140 & 81,440 \\
Milk/cow, ${ }^{1}$ lb & 12,183 & 16,179 & 18,957 \\
Mailbox milk price (\$/cwt) $^{2}$ & 13.95 & 13.02 & 16.06 \\
${\text { Cost of milk }(\$ / \text { cwt })^{3}}^{3}$ & 9.88 & $10.14^{4}$ & $19.22^{5}$ \\
\hline
\end{tabular}

${ }^{1}$ Source of data was USDA NASS (www.nass.usda.gov).

${ }^{2}$ Average price received by farmers for milk that was eligible for fluid milk markets from International Dairy Foods Association (www.IDFA.org).

${ }^{3}$ Cost data are from www.ers.usda.gov/data/costsandreturns/testpick.htm

${ }^{4}$ Data are actually from 1992, as 1994 data were not available.

${ }^{5}$ Data are from 2003 as the 2004 data are not yet available.

education. The authors have elected to provide information on the dairy industry for 3 benchmark years; 1981, 1994, and 2004 (see Table 1). The first year selected was to provide a comparison to data from the 75th anniversary issue of the Journal of Dairy Science (volume 64, issue 6), the 1994 benchmark was selected as a midpoint, and 2004 was the year that survey data was collected for the current review. From 1981 until 2004 , the number of dairy cows continued to decline at a modest rate, the number of dairy farms declined significantly, and the milk production per cow continued to make significant improvement (Table 1). For reference, the national average for mailbox milk price that is not adjusted for inflation is included in Table 1. The final row in Table 1 shows Economic Research Service data for cost to produce a hundredweight of milk, and shows that farmers' costs have increased $95 \%$ in the 25-yr span. The scenario of increasing farm input costs and stagnant milk prices emphasize the need for dairy farmers to improve the efficiency of resource use if they are to stay in business. This requires greater technical education and knowledge, increased use of consultants, increased assumption of risk (because many farms borrowed money for expansion to stay competitive), and a general increase in degree of business sophistication. These market forces have placed significant demands on educational programs in dairy production to remain relevant to the industry, as well as positioned to provide leadership for the future.

\section{Data Collected from Surveys}

A survey was developed and sent to all institutions that the authors identified that offer 4-yr degrees in the dairy production area. This included all 50 landgrant universities as well as several non-land-grant institutions. Follow-up communications were made to increase response rate and to clarify data, as needed.
Responses were received from 38 institutions that award 4-yr degrees. This compared favorably to the 20 to 27 schools used in the summary of Etgen and Foreman. Some of the institutions did not respond to the current survey because courses in dairy science are not offered. A similar survey was sent to 24 institutions that offer course work in dairy production that may lead to a technical degree, and data were collected from 12 institutions that responded. For the purpose of this review, nonbaccalaureate degrees include resident educational programs that lead to technical degrees, associate degrees, or short courses of $17 \mathrm{wk}$ duration; but not short courses of 2 wk duration or less.

The merger of former dairy science departments into combined animal science departments has increased the difficulty in identification of faculty or their distribution of time devoted to dairy sciences. Among the 38 universities that responded to the survey, 7 have "dairy" in the department name. Many dairy manufacturing/technology programs have merged into food science departments. Four universities still have a combined dairy production/dairy foods department. Because of these changes, dairy science is struggling to maintain identity and visibility on many college campuses.

\section{FOUR-YEAR BACCALAUREATE DEGREE PROGRAMS}

\section{Faculty and Staff Resources}

Fiscal constraints, or the decision to not replace positions that become available with faculty retirement, have contributed to a reduction in faculty numbers in the dairy and animal sciences. This survey assessed the full-time equivalents (FTE) of faculty devoted to teaching dairy courses in 1990 and 2004, where 1 FTE is considered $100 \%$ teaching in dairy. In reality, most faculty members at universities in 2004 had a split appointment among teaching, research, and extension; and often devote proportionally less time to teaching undergraduate students. The FTE devoted to the teaching of dairy science/dairy production was $1.93 \mathrm{FTE} /$ institution in 1994 and 1.55 FTE/institution in 2004, or a reduction of $20 \%$ in $10 \mathrm{yr}$ (Table 2). Sixteen of the 38 universities that responded have less than $1 \mathrm{FTE}$ devoted to teaching of dairy production. The educational backgrounds of the faculty members who do the teaching has not changed significantly over this time, as $90.3 \%$ have earned $\mathrm{Ph} . \mathrm{D}$. degrees in the 2004 survey. This compares with $81.5 \%$ of faculty in 1980 as reported by Etgen and Foreman. There was a net loss of FTE at all educational levels in baccalaureate programs in 2004. 
Table 2. A profile of faculty resources and numbers and demographics of students enrolled in 4-yr dairy production programs during 1994 and $2004^{1}$

\begin{tabular}{lcr}
\hline Item & 1994 & 2004 \\
\hline Faculty FTE/university & & 1.55 \\
Number of students/university & 1.93 & \\
1 to 25 & 18 & 21 \\
26 to 40 & 9 & 7 \\
$>40$ & 8 & 8 \\
Total number of students & 1,172 & 1,189 \\
Male, \% & 61 & 46 \\
Female, \% & 39 & 54 \\
Farm/agricultural background, \% & 70 & 64 \\
\hline
\end{tabular}

\footnotetext{
${ }^{1}$ Based upon 38 surveys returned to authors from 4-yr degree granting institutions.

${ }^{2}$ One full-time equivalent (FTE) is defined as one faculty member who spends $100 \%$ of their time teaching in dairy production.
}

\section{Student Numbers and Characteristics}

It is also a challenge to identify students who have a specific dairy interest in some combined animal departments due to the names of majors and programs. However, the survey asked the departments to identify numbers of students and the demographics of these students. The survey indicated that the number of current undergraduates in the 38 programs who have a primary interest in dairy was 1,172 in 1994 and 1,189 in 2004 (see Table 2). Eight universities have more than 40 undergraduate students in their 4-yr programs in 2004 , just as in 1994. Twenty-one institutions have 25 students or less who have expressed a primary interest in dairy, 3 more than in 1994 (Table 2). These programs would average 6 students or less per class, which may be inadequate enrollment to offer classes in some universities. Overall, the changes in total student numbers by enrollment group have not changed significantly between 1994 and 2004 (Table 2).

Continuing the trends noted by Etgen and Foreman, there was a decline in the number of students who came from a farm background ( $70 \%$ in 1994 vs. $64 \%$ in 2004), and there was a significant increase in the number of female students; they comprised 54\% of dairy production students in 2004 (Table 2) compared with 39\% in 1994. The gender distribution in dairy production in 1994 reflected national averages as the National Research Council noted that $37.5 \%$ of all undergraduate students in colleges of agriculture in 1993 were female (NRC, 1995). The 54\% female distribution from the present survey is a higher percentage of females enrolled in dairy production than the $46.4 \%$ national average for all students in colleges of agriculture in 2003 as reported by the Food and Agricultural Education Information System (see www.faeis.usda.gov for 2003 enrollment data).
Table 3. Computer programs used in teaching dairy science courses ${ }^{1}$

\begin{tabular}{|c|c|}
\hline Computer program & $\begin{array}{l}\text { Number of } \\
\text { institutions }\end{array}$ \\
\hline Spreadsheet applications & 29 \\
\hline PC Dart ${ }^{2}$ & 25 \\
\hline Spartan $^{3}$ & 17 \\
\hline Dairy Comp $305^{4}$ & 17 \\
\hline DHI Plus ${ }^{5}$ & 14 \\
\hline${\mathrm{CNCPS} / \mathrm{CPM}^{6}}^{6}$ & 8 \\
\hline DAFOSYM $^{7}$ & 3 \\
\hline Other & 15 \\
\hline
\end{tabular}

${ }^{1}$ Based upon 38 surveys returned by 4 -yr degree granting institutions.

${ }^{2}$ PCDart (www.drms.org/pcdart.htm).

${ }^{3}$ Spartan (www.msu.edu/user/ssl/).

${ }^{4}$ DairyComp 305 (Valley Ag Software, Inc., Tulare, CA).

${ }^{5}$ DHI Plus (www.dhiprovo.com/products_dhiplus.asp).

${ }^{6}$ Cornell Net Carbohydrate and Protein System (www.cncps. cornell.edu) and Cornell, Penn, and Minor program (www.cpmdairy. com).

${ }^{7}$ DAFOSYM = DAiry FOrage SYstem Model (usda.ars.usda.gov/ naa/pswmru).

\section{Computer Software Tools and Information Technology}

A few questions on the survey related to the use of decision-making software tools and the percentage of class time devoted to their use. In $2004,86.8 \%$ of courses in dairy production used computers and information technology compared with $29.9 \%$ of courses in 1994 . In $2004,22.0 \%$ of course time in dairy science involved use of computer programs for dairy farm management compared with $7.0 \%$ of time in 1994 . Not surprisingly, the information age has invaded the dairy production curriculum. Survey respondents were also asked about the specific computer software programs used in the dairy curriculum. Programs for spreadsheet application (such as Excel, QuattroPro) were most frequently used, followed by PC Dart, Spartan, and Dairy Comp 305 (Table 3). Some survey respondents also indicated use of DHI Plus, CNCPS/CPM, or DAFOSYM in their courses; and 15 of 38 institutions reported use of programs in the "other" category (Table 3 ).

\section{Skills and Experiences Deemed Important by Faculty}

Included in the current survey was an assessment of the importance of various skills and experiences for students in dairy science. University faculty members at each institution were asked to rank each of 16 skills or experiences using a rating of 1 (not important), 2 (somewhat important), 3 (important), or 4 (extremely important). The authors ranked these skills after calculating the geometric means for all institutions (Table 
Table 4. Skills and experiences deemed important by faculty in dairy science programs

\begin{tabular}{ll}
\hline & $\begin{array}{l}\text { Mean } \\
\text { response of } \\
\text { importance } \\
\text { (rank) }\end{array}$ \\
Skill/experience & $3.75(1)$ \\
\hline Interpersonal communication skills & $3.71(2)$ \\
Critical-thinking skills & $3.58(3)$ \\
Oral presentation skills & $3.53(4)$ \\
Writing skills & $3.50(5)$ \\
Computer skills & $3.42(6)$ \\
Team problem-solving skills & $3.22(7)$ \\
Leadership development skills & $3.19(8)$ \\
Knowledge of general business management & $3.17(9)$ \\
Industry related internships or work experience & $3.14(10$ tie) \\
Completed capstone course & $3.14(10$ tie) \\
Knowledge of agri-business marketplace & $2.94(12)$ \\
Human resource management & $2.25(13)$ \\
Dairy challenge participation & $2.20(14)$ \\
International experience & $2.14(15)$ \\
Foreign language skills & $2.00(16)$ \\
Dairy cattle-judging experience &
\end{tabular}

${ }^{1}$ Based upon a scale from $1=$ not important to $4=$ extremely important.

4). The top 5 skills as ranked by faculty members who teach undergraduates in dairy science were in the areas of critical thinking, oral and written communication skills, and computer skills. Also ranked very highly were team problem-solving skills (Table 4). A survey of 14 dairy and food industry executives was conducted and published by the Hoard's Dairyman staff (Hoard's Dairyman, 2004), and yielded similar results to this larger faculty survey. The Hoard's survey also placed critical-thinking and interpersonal communication skills as the top priority. Industry executives placed business knowledge and marketing skills somewhat higher than did university faculty members, which is not surprising (Hoard's Dairyman, 2004).

Leadership development, general business and market knowledge, and human resource management were ranked in the middle of the skill-sets rankings by faculty members. The scores received (3.22 to 2.94 ) suggest they are important skills to faculty, but are not as highly ranked as the top 6 skills and experiences (Table 4).

Participation in the North American Intercollegiate Dairy Challenge (NAIDC), international experiences, foreign language skills, and dairy cattle judging were at the bottom of this list with scores that ranged from 2.25 to 2.0 (Table 4). The ranking for the NAIDC may be related to the fact that it is a relatively new activity as reported by Weber Nielsen and colleagues in 2003, and may not yet be fully appreciated. Participation in this industry-sponsored activity has shown steady growth in its first $4 \mathrm{yr}$ (Table 5). This educational activity challenges students from universities to address all
Table 5. Participation in North American Intercollegiate Dairy Challenge ${ }^{1}$

\begin{tabular}{lll}
\hline Year & $\begin{array}{l}\text { Students, } \\
\text { no. }\end{array}$ & $\begin{array}{l}\text { Universities, } \\
\text { no. }\end{array}$ \\
\hline 2002 & 56 & 14 \\
2003 & 96 & 22 \\
2004 & 100 & 23 \\
2005 & 108 & 27 \\
\hline
\end{tabular}

${ }^{1}$ Described by Weber Nielsen et al. (2003).

aspects of a dairy farm business, and to make a presentation of management strategies to improve the business. Thus, it involves many of the skills ranked highly by faculty members in the survey, as it allows students to apply both theoretical and practical knowledge to a dairy farm business. As the NAIDC experience grows with added regional contests, it will provide opportunities for more students to participate.

\section{Initial Careers of Graduates, Internships, and Work Experiences}

A major objective of an undergraduate program is to prepare students for future careers. In the survey, faculty members at the 38 universities were asked to assess the number of graduates over the last $5 \mathrm{yr}$ who selected different career options upon graduation. Information on 1,694 graduates indicated that the most common path for dairy science graduates to follow was dairy farming (or production agriculture); $31 \%$ of students followed this path (Table 6). Approximately 27\% of dairy production graduates elected to enter veterinary or graduate school, and $10 \%$ of graduates entered the feed/nutrition field. The remaining $31 \%$ of students

Table 6. Initial career paths of graduates from 4-yr dairy production programs $^{1}$

\begin{tabular}{lc}
\hline Career path & $\begin{array}{l}\text { \% of } \\
\text { graduates }\end{array}$ \\
\hline Dairy production & \\
Herdsperson or farm worker & 7.6 \\
Herd manager/assistant manager & 7.4 \\
Return to home farm & 16.0 \\
Veterinary school & 16.3 \\
Graduate school & 10.9 \\
Nutrition/feed sales and service & 10.6 \\
Education (includes cooperative extension) & 5.3 \\
Pharmaceutical sales and service & 5.1 \\
Animal breeding (service and sales) & 4.8 \\
Communications (advertising, promotion, & 4.2 \\
and marketing) & 4.0 \\
Finance/business & 3.8 \\
Government/regulatory & 4.0 \\
Other &
\end{tabular}

${ }^{1}$ Data are from results of authors' survey and represent 1,694 graduates over the last $5 \mathrm{yr}$. 
Table 7. Types of internships and experiences by undergraduates in 4-yr programs

\begin{tabular}{ll}
\hline Type of experience & Students, \\
\hline Dairy farm & no. \\
Nutrition/feed industry & 413 \\
AI organizations & 233 \\
Financial/business & 162 \\
Pharmaceuticals & 149 \\
Cooperative extension & 104 \\
Breed organizations & 101 \\
Other & 76 \\
\hline
\end{tabular}

${ }^{1}$ Data are from results of authors' survey and represent 1,363 graduates over the last $5 \mathrm{yr}$.

pursued careers in education, pharmaceutical sales and service, animal genetics and breeding, communications, financial, regulatory, and "other" categories (Table 6).

Internships and work experiences are valued as important components that contribute to an undergraduate education; the survey data indicated that $40.5 \%$ of universities require students to participate in internships or work experiences before graduating with a dairy science degree. In total, 1,363 students (or 273/ yr) participated in internships or work experiences during the 5-yr survey window. There appears to be a relationship between the types of internship and work experiences that students select while earning the baccalaureate degree (Table 7), and what career path they follow upon graduation. This is evident in the relative frequencies in Tables 6 and 7.

\section{University Dairy Farms}

Survey responses indicated that $94 \%$ of universities retain a working dairy farm for teaching or research purposes. The average herd size is 177 milking cows and 11 universities have herds larger than 200 cows. Data indicated that $97 \%$ of universities used cows for research, $100 \%$ made them available for teaching, and that $12 \%(4 / 38)$ had a separate student-managed herd.

\section{Extracurricular Activities that Contribute to Education}

Extracurricular activities such as dairy science clubs are thought to be an important part of the total college experience as they foster leadership, interpersonal skills, and teamwork. Of the universities who responded to the survey, $80 \%$ had a dairy science club, with an average of 27 student members. Seven clubs had more than 45 members; these were the same institutions that had large enrollments as reflected in Table 2 .
Table 8. Faculty resources and demographics of students enrolled in nonbaccalaureate dairy production programs in 1994 and $2004^{1}$

\begin{tabular}{|c|c|c|}
\hline Item & 1994 & 2004 \\
\hline Faculty numbers (FTE/institution) ${ }^{2}$ & 2.5 & 2.7 \\
\hline Total number of students & 304 & 417 \\
\hline No. of programs with $>25$ students & 5 & 7 \\
\hline Male, $\%$ & 86 & 71 \\
\hline Female, $\%$ & 14 & 29 \\
\hline Farm or agricultural background, \% & 83 & 85 \\
\hline
\end{tabular}

${ }^{1}$ Based upon 12 surveys returned to authors from nonbaccalaureate degree granting institutions.

${ }^{2}$ One full time equivalent (FTE) is defined as one faculty member who spends $100 \%$ of their time teaching in dairy production.

Eighty percent of universities that responded to the survey have dairy cattle judging teams. This is in spite of the fact that dairy judging was the lowest-rated skill or experience listed in Table 4. It is clear that this is a very traditional activity within a dairy science curriculum, and one that has support from breed organizations, the breeding industry, and loyal alumni who are vocal in support of this activity. A rating of 2.0 simply means that it has less value in the minds of teaching faculty than the other items listed (Table 4).

\section{NONBACCALAUREATE DEGREE PROGRAMS}

\section{Faculty and Student Resources}

A survey similar to the one used for the baccalaureate degree programs was sent to 24 institutions that offer technical, or nonbaccalaureate degrees. The time required to complete these programs ranged from $17 \mathrm{wk}$ to $2 \mathrm{yr}$. Faculty FTE resources devoted to teaching dairy in these technical programs averaged 2.7 FTE in 2004, or an 8\% increase from 1994 (Table 8). A survey of the educational level of the faculty members in these programs indicated that $40 \%$ had earned the $\mathrm{PhD}$ degree and that $38 \%$ had earned an MS degree. A total of 417 students, or 35/institution, were enrolled in dairy production programs in the 12 institutions that responded to the survey (Table 8). Males represented 71\% of the students enrolled in these programs in 2004, and $85 \%$ of students had dairy farm backgrounds in 2004 . There was a notable increase in number of females in technical programs between 1994 and 2004, but little change in the percentage with farm experience (Table 8).

\section{Skills and Experiences, Internships, and Career Paths}

The faculty members from technical degree institutions who completed the surveys indicated the importance of various skills and experiences for students, as 
was done for the 4-yr degree programs. The scores for all skills were rated highly, with the highest rankings for critical-thinking skills, and team problem-solving skills. The analysis of initial career paths of students from the nonbaccalaureate programs showed that $80 \%$ of graduates over the last $5 \mathrm{yr}$ remained in production agriculture, and that $50 \%$ returned to their home farms. Animal breeding sales and service was a career path for $4.9 \%$ of graduates and all other categories (e.g., animal feed sales, pharmaceutical sales, finances, governmental positions, education) were less common. About $30 \%$ of graduates of these technical programs will eventually go on to complete baccalaureate programs, according to faculty surveys. Internships were required at 10 of the 12 institutions that responded to the survey and $51 \%$ of those internships were on dairy farms. Seventy-five percent of the institutions had access to dairy farms for educational use. Ninety percent of the courses taught used computers and information technology.

\section{DISCUSSION}

There are challenges in educational programming in dairy production, just as there are challenges in all colleges of agriculture. Meyer (1993) stated that there is a clear societal need for the land-grant colleges of agriculture to decrease the emphasis on agriculture, and increase the emphasis on the life sciences, food quality, environmental quality, and the urban-rural interface. Given the increased number of publications on these societal issues and the publicity related to environmental regulation in many states, it appears that our universities have responded to that challenge. However, educational programs in dairy production have not abandoned precision agriculture, dairy management, dairy cattle nutrition, reproduction, or other more traditional disciplines. In fact, as there are more students who hail from nonfarm backgrounds, courses have been added at some institutions to teach students routine aspects of animal management that previously were assumed skills (Reiling et al., 2003).

Huge advances in biotechnology, genome mapping, genetic manipulation, and computer and information technology occurred over the last $25 \mathrm{yr}$. In 1995, Gherty discussed the speed of change in the information age, and suggested that universities need to focus on the customer, develop a clear vision, maintain a critical mass of faculty, and emphasize teamwork more than in the past. This need for faculty members to adapt to a rapidly evolving world presents a challenge as the faculty FTE per institution decline whereas total numbers of students with an interest in dairy production have not (Table 2). In reference to hiring students with a baccalaureate degree, Gherty emphasized that dairy corporations would prefer that universities emphasize general education at the expense of technical knowledge simply due to the speed of change. In contrast, many farmers and other small businesses may want to hire students who have more practical knowledge. Weber-Nielsen (2003) indicated that a significant thrust behind the formation of the NAIDC was that more students came from nonfarm backgrounds so there was a need to improve the practical skills necessary to join a competitive dairy industry. This is consistent with observations of Meyer (1990) who noted that alumni from the animal science program indicated the desire for more practical subject matter in the curriculum.

Braund (1995) warned institutions of higher education about a problem with land-grant universities losing credibility with the public, and emphasized the need for academicians to adhere to a higher level of accountability in the use of public funds. Hodges (2003) provided a sobering view of the animal sciences resulting from the reported link between bovine spongiform encephalopathy and variant Creutzfeld-Jakob disease in humans, stating that animal scientists have lost credibility with European society. He further argued for a shift from the "era of intensification" to a "quality of life agriculture era." It is possible that the European view of animal production and the dairy industry differs from that in North America, but it remains in our best interest to self-evaluate our programs and priorities. These opinions lead to a number of important questions. Do current programs overemphasize intensification and animal productivity? Have we accurately identified our customer? Is there adequate emphasis on quality of life in teaching dairy production? In the view of the authors, economic realities about dairy production in the United States (see Table 1) require that precision farming and a significant financial orientation must continue in our programs if we are to serve our students, but we must also be mindful of issues that affect our image and credibility with the public.

Grant and colleagues (2000) reviewed the state of undergraduate education in the animal sciences, and noted a trend toward increased specialization at the expense of more general education. They stated that many of today's students lack the skill and knowledge required to solve problems. The opinions of Grant and colleagues toward the desired intellectual skills of graduates are consistent with those stated by Gherty (1995). Peters and associates (2002) have described a process to develop critical-thinking skills in the classroom, and report a positive experience for the great majority of students.

Meeker (1999) reminded academicians that many in the animal industries have the perception that univer- 
sity faculties are arrogant and unresponsive to the needs of the industry. This perception may be a barrier to success in garnering financial support for programs at universities. The frequency of internships taken by dairy students, and the correlation between internships and initial employment (Tables 6 and 7) would argue that academic programs today are relevant to the dairy industry. The need for excellent critical-thinking and communication skills in graduates of our baccalaureate programs were emphasized by Haug (1996) and Lauderdale (1999) and are consistent with views of educators in dairy production at this time (Table 4).

Barnes and coauthors (1999) reviewed some of the keys to success in using Internet-based resources to teach a course in animal science, and the results of the current survey suggest that information technology has been incorporated very well into current dairy production curricula. This advance in technology and the increased comfort level of future graduates in using computer technology and the World Wide Web predicts the opportunity to reach a new audience any time and anywhere in the future. Outreach programs will cross the borders of states and even countries in the future; thus, educational programs will have to be timely and relevant to remain competitive.

Survey results indicated that educators in dairy production rate international experience at 2.14 on a 4.0 scale of importance (Table 4). In spite of the fact that most dairy food companies are now international in scope (Marshall, 2001), Forsberg and colleagues (2003) concluded that relatively few animal science undergraduate programs had incorporated internationalization into their curricula, and relatively few students participate in international programs. Moreover, most faculties realize the importance of providing an international view of the animal sciences, but resources may be limiting to provide more of these experiences.

Although there is no shortage of challenges for dairy production educational programs, there is reason for optimism as well. Enrollments in baccalaureate degree programs have remained stable and enrollments in nonbaccalaureate degree programs have increased over the last $10 \mathrm{yr}$. Perhaps the need to include more biotechnology, information technology, and business into the curriculum at universities has allowed other institutions (like the technical degree granting institutions) to fill the gaps for practically trained farm workers. The initiation of new educational activities such as NAIDC and the opportunity for numerous internships in the private sector is evidence that universities, colleges, and the dairy industry are engaged in partnerships to provide the work force needed for the dairy industry to remain competitive in the global marketplace.

\section{CONCLUSIONS}

The state of baccalaureate and technical education in dairy production is very good as enrollments remain stable, educational programs remain relevant to the dairy industry, curricula have evolved to incorporate software tools and information technology, and a high percentage of students remain in the industry after graduation. There has been some loss of faculty FTE in baccalaureate programs and some gain in faculty FTE in technical programs since 1994. There is a continued trend for more females enrolled and fewer students with dairy farm experience in the baccalaureate programs, but males and students with dairy farm backgrounds continue to predominate in the technical programs.

It remains to be seen if continued consolidation in the dairy industry (fewer farms and fewer firms) leads to the point where there is reduced demand for employees with education in dairy-related fields. There is a concern that institutions in some states may be struggling to maintain visibility and critical mass of faculty and students with an interest in dairy. However, there remain clusters of programs with significant numbers of dairy-oriented students in the northeast, upper Midwest, and far west; regions that also have significant cow numbers. The trend for erosion in the USDA formula funds necessary to support dairy science programs at land-grant institutions, and the increased challenge of maintaining cutting-edge educational programs in dairy production are stressing the infrastructure. It appears that strong interaction with private industry, including financial support for teaching and research programs, may be necessary to ensure viable educational programs in the future. The more creative and energetic faculties will devise methods to meet teaching objectives.

\section{ACKNOWLEDGMENTS}

The authors need to thank the numerous faculty members from around the United States who were willing to complete our survey and provide the valuable data used for this review.

\section{REFERENCES}

Barnes, D. M., J. P. Simms, and W. Jamison. 1999. Use of Internetbased resources to support an introductory animal and poultry science course. J. Anim. Sci. 77:1306-1313.

Braund, D. G. 1995. Changing paradigms in animal agriculture: The role of academia and industry in technology transfer. J. Anim. Sci. 73:3173-3177.

Etgen, W. M., and C. F. Foreman. 1981. Trends in dairy science education-Production. J. Dairy Sci. 64:906-916.

Forsberg, N. E., J. S. Taur, Y. Xiao, and H. Chesbrough. 2003. Internationalization of the animal science undergraduate curriculum: A 
survey of its current status, barriers to its implementation and its value. J. Anim. Sci. 81:1088-1094.

Gherty, J. 1995. Serving the customer! Education's challenge for the future. J. Dairy Sci. 78:1399-1406.

Grant, P. M., T. G. Field, R. D. Green, and B. E. Rollin. 2000. The importance of comprehensive agricultural education in land grant universities: A historical perspective. J. Anim. Sci. 78:1684-1689.

Haug, M. 1996. How to incorporate and evaluate writing skills in animal science and dairy science courses. J. Anim. Sci. 74:2835-2842.

Hoard's Dairyman. 2004. Dairy science education faces challenges. Hoard's Dairyman 149:559.

Hodges, J. 2003. Livestock, ethics, and quality of life. J. Anim. Sci. 81:2887-2894.

Lauderdale, J. W. 1999. What is the pharmaceutical industry doing, and what does the pharmaceutical industry want from animal science departments? J. Anim. Sci. 77:367-371.

Marshall, R. T. 2001. Issues of education for dairy food scientists: Food science vs. dairy science. J. Dairy Sci. (E Suppl.):E187-E188.

Meeker, D. L. 1999. What are livestock industries doing, and what do they need from us? J. Anim. Sci. 77:361-366.
Meyer, J. H. 1990. Influence of alumni careers and student's educational pathways on animal science undergraduate teaching programs. J. Anim. Sci. 68:3056-3068.

Meyer, J. H. 1993. The stalemate in food and agricultural research, teaching and extension. Science 260:881, 1007.

NRC. 1995. Chapter 3: The Colleges of Agriculture. Academic Programs and Demographics of Students and Graduates. Pages 3457 in Colleges of Agriculture at the Land Grant Universities: A Profile. National Academy Press, Washington, DC.

Peters, M. W., M. F. Smith, and G. W. Smith. 2002. Use of critical interactive thinking exercises in teaching reproductive physiology to undergraduate students. J. Anim. Sci. 80:862-865.

Reiling, B. A., T. T. Marshall, J. H. Brendemuhl, J. A. McQuagge, and J. E. Umphrey. 2003. Experiential learning in the animal sciences: Development of a multispecies large-animal management and production practicum. J. Anim. Sci. 81:3202-3210.

Weber Nielsen, M. S., J. J. Domecq, L. E. Davis, D. K. Beede, M. Budine, and F. Martsolf. 2003. A partnership of universities and agri-business for an effective dairy herd management learning experience for undergraduates: The dairy challenge. J. Dairy Sci. 86:1029-1035. 